\title{
Determination of Trace Metals in Electrolytic Copper by ICP OES and ICP-MS
}

\author{
Éder José dos Santos ${ }^{1}$, Amanda Beatriz Herrmann ${ }^{1}$, José Luiz Olkuszewski ${ }^{1}$, Tatiana D. \\ Saint'Pierre ${ }^{2}$ and Adilson José Curtius ${ }^{2^{*}}$ \\ ${ }^{1}$ Instituto de Tecnologia do Paraná - TECPAR; C. P. 357; eder@tecpar.br; 81350-010; Curitiba - PR - Brasil. \\ ${ }^{2}$ Universidade Federal de Santa Catarina -UFSC; C. P. 476; curtius@qmc.ufsc.br; 88040-900; Florianópolis - \\ SC - Brasil
}

\begin{abstract}
The performance of axial view ICP OES and ICP-MS techniques were compared through the determination of As, $\mathrm{Fe}, \mathrm{Mn}, \mathrm{Pb}, \mathrm{Sb}$ and $\mathrm{Sn}$ in electrolytic copper. Samples were prepared by two procedures: 1. Total dissolution with $5 \% \mathrm{v} / \mathrm{v} \mathrm{HNO}_{3}$ and 2. Dissolution with $1.4 \% \mathrm{v} / \mathrm{v} \mathrm{HNO}_{3}$ plus $2.0 \% \mathrm{v} / \mathrm{v} \mathrm{H}_{2} \mathrm{SO}_{4}$, followed by separation of the Cu by electrodeposition. The methods were applied for the analysis of standard copper solutions, using calibration against aqueous solutions with or without the addition of $\mathrm{Cu}$. The results obtained by the two techniques were similar, but the separation of $\mathrm{Cu}$ from the sample matrix proved to be more adequate for practical reasons.
\end{abstract}

Key words: ICP-MS, axial view ICP OES, electrolytic copper, electrodeposition

\section{INTRODUCTION}

Copper is a major component of several metal alloys because of its malleability and excellent electrical and thermal conductivities. Copper alloys are employed in many industrial sectors. Electrolytic copper is used mainly in electricity, electronic devices and in many other applications (Lemos and Arantes, 1982; Fodes, 1973; ASM, 1988). The allowed concentration limits of trace metals, such as $\mathrm{Fe}, \mathrm{Pb}$ and $\mathrm{Sn}$, in electrolytic copper are very low, according to ASM (1988), ASTM (1990), and JIS (1988), since some elements can deteriorate the alloy characteristics, such as the electric conductivity. The allowed concentration limits vary according to the utilization purpose of the sample and, for electrolytic copper, they are, in $\mathrm{mg} \mathrm{kg}^{-1}$ : As: 10; Fe: 100; Mn: 50; Sb: 10; Sn: 10 and Pb: 50 (Metals Handbook, 1979). For this reason, the concentration of impurities should be under control to guarantee the quality of copper alloys. The analysis of this kind of material is recommended to be carried out by atomic absorption spectrometry and UV/VIS spectrophotometry, according to ASTM and JIS. In addition, the sample preparation is a very important step of the analysis and should be optimized to each matrix.

The ICP techniques, inductively coupled plasma optical emission spectrometry (ICP OES) (Nham, 1999) and inductively coupled plasma mass spectrometry (ICP-MS) (Jarvis, Gray and Houk, 1992), allow multielemental detection, low limits of detection and good precision, ideal for the industrial routine analysis that, usually, require fast and

\footnotetext{
*Author for correspondence
} 
highly sensitive techniques. In this sense, the determination of trace metals in copper samples can be difficult by the presence of high quantities of copper in solution, which can promote interferences and contamination of the nebulization system. In ICP-MS, the corrosion of the sampler and skimmer cones should also be taken under consideration.

Some works have developed methods for the determination of trace elements in electrolytic copper. Chiba et al. (1990) determined Sb and Ag in electrolytic copper by isotope dilution (ID ICPMS) with preconcentration of the analytes by coprecipitation. A more efficient method was proposed by Park et al. (1992) using previous electrodeposition of the $\mathrm{Cu}$ before the determination of $\mathrm{Ni}, \mathrm{Zn}, \mathrm{Ag}, \mathrm{Sb}$ and $\mathrm{Pb}$ by ID ICP-MS. Milella et al. (1993) investigated impurities in high-purity electrolytic copper by Zeeman graphite furnace atomic absorption spectrometry and more recently Kumar et al. (2004) investigated two different procedures, (i) co-precipitation of metal hydroxides using $\mathrm{La}$ as carrier and (ii) electrodeposition of $\mathrm{Cu}$ for determination of impurities by F AAS and GF AAS.
In this work, the performances of ICP-MS and axially ICP OES were compared through the determination of $\mathrm{As}, \mathrm{Fe}, \mathrm{Mn}, \mathrm{Pb}, \mathrm{Sb}$ and $\mathrm{Sn}$ in electrolytic copper. Two methods for sample preparation were also compared, i.e., total dissolution without and with copper separation by electrodepositon.

\section{MATERIALS AND METHODS}

\section{Instrumentation}

A Varian Vista Pró (Melbourne, Australia) axially inductively coupled plasma atomic absorption spectrometer (ICP OES) and a Perkin Elmer Sciex Elan 6000 (Tornhill, Toronto, Canada) inductively coupled plasma mass spectrometer with pneumatic nebulization were used to carry out the measurements. A Yanaco Co. (Kobe, Kyoto, Japan) AES 2D - Y1550 electroanalyser, equipped with high purity $\mathrm{Pt}$ electrodes was employed to separate $\mathrm{Cu}$ from the analytes. The ICP OES and ICP-MS operational conditions are described in Table 1.

Table 1 - ICP OES and ICP-MS operational conditions.

\begin{tabular}{lcc}
\hline Parameters & ICP-MS & ICP OES \\
\hline RF power, $\mathrm{W}$ & 1000 & 1000 \\
Plasma gas flow rate, $\mathrm{L} \mathrm{min}^{-1}$ & 15 & 15 \\
Auxiliary gas flow rate, $\mathrm{L}$ & 1.2 & 1.5 \\
min $^{-1}$ & & \\
Carrier gas flow rate, $\mathrm{L} \mathrm{min}^{-1}$ & 1.04 & 1.0 \\
Scan/reading & 50 & 10 \\
Reading/replicate & 1 & 1 \\
Replicates & 3 & 3 \\
Detector & Dual & $\mathrm{CCD}$ \\
Cones sampler/skimmer & $\mathrm{Pt}$ & $\mathrm{Pt}$ \\
\hline
\end{tabular}

The spectral lines and the analytes isotopes selected for the analysis by ICP OES and ICP-MS, respectively, were chosen in order to obtain maximum sensitivity and minimum interference, and are shown in Table 2. For ICP OES, all selected spectral lines were free from interference. The background emission was compensated by the preparation of the sample and calibration solutions in the same media.

For ICP-MS, ${ }^{208} \mathrm{~Pb},{ }^{121} \mathrm{Sb}$ and ${ }^{120} \mathrm{Sn}$ were the chosen isotopes, since these were the most abundant isotopes and free from interference in this sample matrix. Manganese is monoisotopic, ${ }^{55} \mathrm{Mn}$, and can suffer spectral interference by $\mathrm{ArN}, \mathrm{ClO}$ and $\mathrm{HClO}$ ions. However, these interferences are not significant at low nitric and chloride concentrations (Jarvis et al. 1992; ELAN 6000, 1989). Arsenic is also monoisotopic, ${ }^{75}$ As, but the possible interferences are not significant in this situation. 
Table 2 - Selected spectral lines and isotopes for the analysis by ICP OES and ICP-MS, respectively.

\begin{tabular}{ccc}
\hline Analyte & ICP OES (Spectral lines, nm) & ICP-MS (Isotope abundance, \%) \\
\hline $\mathrm{As}$ & 193.696 & ${ }^{75} \mathrm{As}(100)$ \\
$\mathrm{Fe}$ & 238.204 & ${ }^{57} \mathrm{Fe}(2.2)$ \\
$\mathrm{Mn}$ & 257.610 & ${ }^{55} \mathrm{Mn}(100)$ \\
$\mathrm{Sb}$ & 206.834 & ${ }^{121} \mathrm{Sb}(57)$ \\
$\mathrm{Sn}$ & 189.925 & ${ }^{220} \mathrm{Sn}(33)$ \\
$\mathrm{Pb}$ & 220.353 & ${ }^{208} \mathrm{~Pb}(52.3)$ \\
\hline
\end{tabular}

The most abundant $\mathrm{Fe}$ isotopes, ${ }^{56} \mathrm{Fe}(92 \%)$ and ${ }^{54} \mathrm{Fe}(6 \%)$, are subjected to critical interference by $\mathrm{ArO}$ and $\mathrm{ArN}$ ions. In this case, a less abundant isotope has to be selected, ${ }^{57} \mathrm{Fe}(2.2 \%)$, since the interference by $\mathrm{ArO}$ over this isotope is much less significant.

\section{Reagents and Solutions}

All chemical reagents were of analytical grade. Water (resistivity of $18.2 \mathrm{M} \Omega \mathrm{cm}$ ) was de-ionized in a Milli-Q system (Millipore, Bedford, MA, USA). A $65 \%$ v/v nitric acid (No. 100452) and 95-97 \% v/v sulfuric acid (No. 100731) both from Merck (Darmstadt, Germany) were used for the preparation of samples, calibration solutions and blanks. Individual $1000 \mathrm{mg} \mathrm{L}^{-1}$ aqueous stock solutions of As (No.119773), Fe (No.109972), Mn (No.19789), Pb (No.119776), Sb (No.109920) and Sn (No.9929) were also from Merck and a 10.000 $\mathrm{mg} \mathrm{L}^{-1}$ of $\mathrm{Cu}$ solution (No.14372) was from Specpure (Warn Hill, MA, USA).

\section{Calibration solutions}

Two series of calibration solutions containing 5, 10 and $20 \mu \mathrm{g} \mathrm{L}^{-1}$ of As, 50, 100 and $200 \mu \mathrm{g} \mathrm{L}^{-1}$ of Fe, $\mathrm{Mn}, \mathrm{Sb}$ and $\mathrm{Sn}$, each one, and 100, 500 and 1000 $\mu \mathrm{g} \mathrm{\textrm {L } ^ { - 1 }}$ of $\mathrm{Pb}$ were prepared in two different media: calibration 1 (matrix matching): $5 \%$ v/v $\mathrm{HNO}_{3}$ containing $0.2 \% \quad \mathrm{w} / \mathrm{v} \mathrm{Cu}$ and calibration 2 (conventional calibration): $2 \% \mathrm{v} / \mathrm{v} \mathrm{H}_{2} \mathrm{SO}_{4}$ and 1.4 $\% \mathrm{v} / \mathrm{v} \mathrm{HNO}_{3}$, without addition of $\mathrm{Cu}$.

\section{Certified standard solutions}

Calibration solutions were prepared by dilution of certified standard solutions APS 1031, 1032 and 1033 from Alpha Resources (Stevensville, Michigan, USA) in the same media of the calibration solutions, with and without addition of $0.2 \% \mathrm{w} / \mathrm{v} \mathrm{Cu}$, to a final concentration of $50 \mu \mathrm{g} \mathrm{L}^{-1}$ of As, Fe and $\mathrm{Mn} ; 100 \mu \mathrm{g} \mathrm{L}^{-1}$ of $\mathrm{Sb}$ and $\mathrm{Sn}$ and $500 \mu \mathrm{g} \mathrm{L}^{-1}$ of $\mathrm{Pb}$.

\section{Samples}

Eight samples were analyzed: three commercial electrolytic copper and five more from different industries.

Sample 1 was from Divisão QM Reagentes (São Paulo, SP, Brazil, catalog no. 13060),sample 2 was from Vetec Química Fina (Rio de Janeiro, RJ, Brazil, no. 676) and sample 3 from Merck (no. 2715). They were prepared by two different procedures and then analyzed by ICP OES and by ICP-MS: Total dissolution: $0.2 \mathrm{~g}$ were dissolved in $10 \mathrm{~mL} 50 \% \mathrm{v} / \mathrm{v} \mathrm{HNO}_{3}$ under heating (around 90 ${ }^{\circ} \mathrm{C}$ ) and diluted to a $100 \mathrm{~mL}$ final volume. Electrodeposition: $1 \mathrm{~g}$ was dissolved in a mixture of $10 \mathrm{~mL} \mathrm{H}_{2} \mathrm{SO}_{4}$ plus $7 \mathrm{~mL} \mathrm{HNO}_{3}$ plus $30 \mathrm{~mL}$ water, under heating (around $90{ }^{\circ} \mathrm{C}$ ), and diluted to $300 \mathrm{~mL}$. The solution was submitted to the $\mathrm{Cu}$ electrodeposition process in the electroanalyzer by applying a current of $3 \mathrm{~A}$ to the electrodes for $2 \mathrm{~h}$. This process follows the ASTM and JIS methodologies for the determination of $\mathrm{Cu}$ by electrogravimetry (ASTM, 1990; JIS, 1988). The resulting solution was colorless and the volume was made up with water to $500 \mathrm{~mL}$. The same procedure was applied to the standard solutions containing $\mathrm{Cu}$, in order to verify the efficiency of the separation step. The samples 4 to 8 from: Volvo do Brasil Veículos Ltda, Tupy Fundições Ltda, Summer Ltda and Daher Tecnologia were analyzed by ICP-MS and ICP OES through the electrodeposition procedure.

\section{RESULTS AND DISCUSSION}

Two methods of calibration (matrix matching and conventional calibration) were employed for the 
analysis by two different techniques (ICP OES and ICP-MS). The linearities of the calibration curves, expressed as the correlation coefficient, were good, better than 0.99 for all analytes by both techniques. The limits of detection (LOD) were very low, better by ICP-MS than by ICP OES, except for Fe, as expected, and especially for $\mathrm{Sb}$ and $\mathrm{Sn}$, as could be seen in Table 3.

The limit of detection is defined (Thompson, 1987) as the analyte concentration equivalent to three times the standard deviation of ten measurements of the blank. The LOD for Fe in solutions containing $\mathrm{Cu}$ was better by ICP OES than by ICP-MS, probably because of the low sensitivity of $\mathrm{Fe}$ in consequence of the low abundance of the selected isotope. It can be also observed that, by ICP OES, the LODs were similar for all analytes in the solutions containing $\mathrm{Cu}$ or not, except for $\mathrm{Pb}$. This happen by the formation of $\mathrm{PbSO}_{4}$ by the presence of $\mathrm{H}_{2} \mathrm{SO}_{4}$ in the solutions with $\mathrm{Cu}$ that could decrease the efficiency of emission of this analyte, producing lower sensitivity.

Table 3 - Correlation coefficients $\left(\mathrm{R}^{2}\right)$ and limits of detection (LOD) in the solution*, in $\mu \mathrm{g} \mathrm{L}^{-1}$, for conventional calibration and matrix matching calibration by ICP OES and ICP-MS.

\begin{tabular}{ccccccccc}
\hline & \multicolumn{3}{c}{ Conventional calibration } & \multicolumn{4}{c}{ Matrix matching } \\
\hline & \multicolumn{2}{c}{ ICP OES } & \multicolumn{2}{c}{ ICP-MS } & \multicolumn{2}{c}{ ICP OES } & \multicolumn{2}{c}{ ICP-MS } \\
\hline Analyte & $\mathrm{R}^{2}$ & LOD & $\mathrm{R}^{2}$ & LOD & $\mathrm{R}^{2}$ & LOD & $\mathrm{R}^{2}$ & LOD \\
\hline $\mathrm{As}$ & 1.00000 & 10 & 0.999999 & 4 & 1.00000 & 10 & 0.999907 & 0.1 \\
$\mathrm{Fe}$ & 0.999929 & 1 & 0.999994 & 0.5 & 1.000000 & 1 & 0.999909 & 3 \\
$\mathrm{Mn}$ & 0.999999 & 0.5 & 0.999975 & 0.1 & 0.999942 & 0.5 & 0.999999 & 0.3 \\
$\mathrm{Sb}$ & 0.999459 & 30 & 0.999613 & 0.005 & 0.996018 & 30 & 0.999656 & 0.01 \\
$\mathrm{Sn}$ & 0.998682 & 25 & 0.999409 & 0.03 & 0.999837 & 30 & 0.999582 & 0.4 \\
$\mathrm{~Pb}$ & 0.999937 & 10 & 1.000000 & 0.1 & 0.999983 & 5 & 0.999957 & 0.2 \\
\hline
\end{tabular}

*The LOD in the sample, in $\mathrm{mg} \mathrm{kg}^{-1}$, is the LOD in solution divided by 2 (considering the sample dissolution procedure).

The sensitivity of $\mathrm{As}, \mathrm{Sb}$ and $\mathrm{Sn}$ by ICP OES were close to or lower than the limit concentrations in electrolytic copper samples, recommended by the ASM (1988). That mean that the determination of these elements in electrolytic copper could not be accurate by ICP OES, requiring a lower sample dilution. Alternatively, the determination of As, $\mathrm{Sb}$ and $\mathrm{Sn}$ close to the limit concentrations could be efficiently carried out by the coupling of a hydride generator to the ICP OES, since this sample introduction accessory allowed higher sensitivities than the pneumatic nebulization, for these elements (VARIAN, 2000; Caruso and Wolnik, 1987).

\section{Evaluation of the electrodeposition efficiency}

In an ideal separation procedure, the separation efficiency should be as closer to $100 \%$ as possible. However, normally some co-precipitation or partial separation can occur, leading to analyte loss or even to some contamination.
In order to verify the separation procedure efficiency, certified standard solutions with the addition of $0.2 \% \mathrm{w} / \mathrm{v} \mathrm{Cu}$ were submitted to the separation process and the concentrations of the analytes were determined by ICP OES. The recovery of the analytes were close to $100 \%$, except for $\mathrm{Fe}$ and $\mathrm{Sn}$, which recovery values were high, possibly indicating the occurrence of some contamination during the copper electrodeposition. The same procedure was applied to a blank solution and the average concentrations and recovery values for a calibration solution and for the blank are shown in Table 4.

The measured values in the blank solution confirmed the contamination by $\mathrm{Fe}$ and $\mathrm{Sn}$ during the procedure, probably due to the contact of the acid vapors with the electrode holders, during the heating. An adequate optimization of the procedure, not tried in this work, would probably minimize the contamination. 


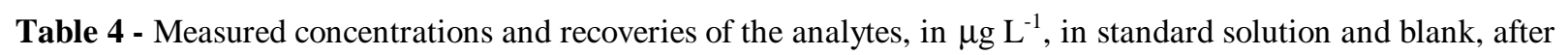
electrodeposition of the $\mathrm{Cu}$, by ICP OES.

\begin{tabular}{ccccc}
\hline Analyte & Certified conc. & Measured conc. & Recovery, \% & Blank conc. \\
\hline $\mathrm{As}$ & 50 & $50 \pm 0.7$ & $100 \pm 1.4$ & nd \\
$\mathrm{Fe}$ & 50 & $129 \pm 62$ & $256 \pm 124$ & $153 \pm 30$ \\
$\mathrm{Mn}$ & 50 & $50 \pm 0.1$ & $100 \pm 0.2$ & nd \\
$\mathrm{Sb}$ & 100 & $101 \pm 2$ & $101 \pm 2$ & nd \\
$\mathrm{Sn}$ & 100 & $117 \pm 15$ & $117 \pm 15$ & $77 \pm 8$ \\
$\mathrm{~Pb}$ & 500 & $429 \pm 5$ & $98.4 \pm 1.0$ & nd \\
\hline
\end{tabular}

nd $=$ not detected

\section{Determination of the analytes in standard solutions by ICP OES and ICP-MS}

The calibration solutions prepared with the certified standards, with and without the addition of $\mathrm{Cu}$, were analyzed by ICP OES and by ICP-MS and the measured concentrations are shown in Table 5.

The results obtained by ICP OES were satisfactory using calibration samples with or without $\mathrm{Cu}$.
However, the measured concentrations by ICP-MS for solutions without $\mathrm{Cu}$ were closer to the certified values than for solutions containing $\mathrm{Cu}$. It was observed that, the presence of high quantities of $\mathrm{Cu}$ in the solution led to the formation of deposits on the torch and cones and, after some time, could promote the corrosion of the sampler cone surface.

Table 5 - Concentrations, in $\mu \mathrm{g} \mathrm{L}^{-1}$ obtained for the analytes in standard solutions with or without $\mathrm{Cu}$, by ICP OES and ICP-MS.

\begin{tabular}{cccccc}
\hline & \multicolumn{2}{c}{ Conventional calibration } & \multicolumn{2}{c}{ Matrix matching } \\
\hline Analyte & Certif. conc. & ICP OES & ICP-MS & ICP OES & ICP-MS \\
\hline $\mathrm{As}$ & 50 & $51 \pm 3$ & $48 \pm 0.5$ & $44 \pm 8$ & $45 \pm 0.2$ \\
$\mathrm{Fe}$ & 50 & $47 \pm 1$ & $48 \pm 1$ & $48 \pm 1$ & $45 \pm 0.1$ \\
$\mathrm{Mn}$ & 50 & $47 \pm 1$ & $50 \pm 0.2$ & $48 \pm 1$ & $45 \pm 0.2$ \\
$\mathrm{Sb}$ & 100 & $102 \pm 5$ & $102 \pm 0.7$ & $101 \pm 3$ & $92 \pm 1$ \\
$\mathrm{Sn}$ & 100 & $96 \pm 3$ & $101 \pm 0.5$ & $99 \pm 3$ & $89 \pm 2$ \\
$\mathrm{~Pb}$ & 500 & $501 \pm 5$ & $490 \pm 3$ & $498 \pm 14$ & $497 \pm 2$ \\
\hline
\end{tabular}

This was observed in both techniques, but the corrosion of the cone was more critical in the ICPMS instrument. In addition, by ICP-MS, the high quantities of $\mathrm{Cu}$ in solution led to lower than expected concentration values, in spite of the matrix matching calibration. Probably, the deposit of copper on the cones surface promote the decreasing of the sensitivity for the other analytes. For this reason, the analysis of electrolytic copper by ICP-MS is recommended only after the previous separation of the $\mathrm{Cu}$, i.e., the matrix matching is not recommended in this case. Since the ICP-MS technique has a very high sensitivity for these analytes, an alternative approach, not attempted in this work, would be to dilute the sample and calibration solutions, in order to reduce the amount of $\mathrm{Cu}$ in the solution, probably, improving the accuracy of the method. However, for the determination of As, usually in low concentrations, an additional dilution would make the analysis not feasible. For this reason, in spite of the risks of contamination, the dissolution followed by the copper electrodeposition appeared to be the best choice for sample preparation in the analysis of electrolytic copper by ICP-MS.

The Student's $t$ test was applied to the obtained concentration values, according to

Leite (2002) and Vogel (1992) and the results were satisfactory at $95 \%$ confidence level for both techniques. Comparing both techniques, no was observed significant differences a $95 \%$ confidence level, when the paired t-test was applied. However, the precision obtained by ICP-MS was better than by ICP OES, as could be seen by the relative standard deviation values in Table 5. 
The measured concentrations of the analytes in the three studied electrolytic copper samples were lower than the LODs of the methods, except for Fe in all samples, and for $\mathrm{As}, \mathrm{Pb}, \mathrm{Sb}$ and $\mathrm{Sn}$ in sample 2. The contamination of $\mathrm{Fe}$ during the copper electrodeposition process also occurred in this case for all samples, confirmed by the high obtained $\mathrm{Fe}$ concentration values. By ICP OES, the concentration of $\mathrm{Fe}$ in the samples subjected to the separation were, in general, one order of magnitude higher than the obtained values using matrix matching calibration, which were, in $\mathrm{mg} \mathrm{kg}^{-1}: 2.5 \pm$ 0.2 (sample 1), $4.5 \pm 1.2$ (sample 2) and $4.7 \pm 0.1$ (sample 3). Only in sample 2, the other analytes could be measured: As $\left(2.5 \pm 0.1 \mathrm{mg} \mathrm{kg}^{-1}\right), \mathrm{Sb}(5.6$ $\left.\pm 0.3 \mathrm{mg} \mathrm{kg}^{-1}\right)$ and $\mathrm{Sn}\left(13.0 \pm 0.7 \mathrm{mg} \mathrm{kg}^{-1}\right)$ by ICPMS using external calibration, after separation by electrodeposition. In Sample 2, Sb (4.2 $\left.\pm \mathrm{mg} \mathrm{kg}^{-1}\right)$ could also be measured by ICP-MS, without separation, using matrix matching calibration. In this sample, $\mathrm{Pb}$ was obtained by ICP OES (42.6 $\left.\pm 2.4 \mathrm{mg} \mathrm{kg}^{-1}\right)$ and by ICP-MS $\left(36.6 \pm 0.9 \mathrm{mg} \mathrm{kg}^{-1}\right)$ using matrix matching calibration. For samples 4 to 8 , the determination of the impurities was carried out by ICP-MS and ICP OES using external calibration, after separation by electrodeposition. The results are presented in Table 6. All found concentrations were below the limits established by ASM, 1988 for electrolytic copper with the exception for $\mathrm{Sn}$ in the samples 5 and 6.

Table 6 - Concentrations, in $\mathrm{mg} \mathrm{kg}^{-1}$, obtained for the analytes by ICP-MS using external calibration, after separation of $\mathrm{Cu}$ by electrodeposition, in samples 4 to $8(\mathrm{n}=3)$.

\begin{tabular}{cccccccc}
\hline \multirow{2}{*}{ Sample } & Technique & \multicolumn{7}{c}{ Analyte } \\
\cline { 3 - 8 } 04 & ICP-MS & nd & $12.1 \pm 0.1$ & 0.08 & $0.15 \pm 0.00$ & $1.18 \pm 0.01$ & $0.78 \pm 0.01$ \\
& ICP OES & nd & $13.6 \pm 0.7$ & nd & nd & nd & nd \\
05 & ICP-MS & nd & $73.6 \pm 0.7$ & $0.12 \pm 0.01$ & $2.24 \pm 0.01$ & $74.15 \pm 1.10$ & $5.32 \pm 0.03$ \\
& ICP OES & nd & $74.4 \pm 0.8$ & nd & nd & $76.4 \pm 2.7$ & $5.3 \pm 0.2$ \\
06 & ICP-MS & nd & $53.5 \pm 0.4$ & $0.64 \pm 0.01$ & $1.85 \pm 0.01$ & $141.60 \pm 0.12$ & $14.80 \pm 0.12$ \\
& ICP OES & nd & $54.2 \pm 0.9$ & $0.67 \pm 0.02$ & nd & $143.2 \pm 3.1$ & $15.1 \pm 1.0$ \\
07 & ICP-MS & nd & $30.1 \pm 1.3$ & $0.18 \pm 0.02$ & $4.84 \pm 0.05$ & $1.54 \pm 0.15$ & $1.15 \pm 0.15$ \\
& ICP OES & nd & $31.9 \pm 0.2$ & nd & nd & nd & nd \\
08 & ICP-MS & nd & $10.6 \pm 0.1$ & $0.10 \pm 0.01$ & $0.70 \pm 0.01$ & $0.38 \pm 0.01$ & 0.45 \\
& ICP OES & nd & $11.5 \pm 0.5$ & nd & nd & nd & nd \\
\hline
\end{tabular}

*nd: not detectable at level of $2 \mathrm{mg} \mathrm{kg}^{-1}$ (ICP-MS) and of $5 \mathrm{mg} \mathrm{kg}^{-1}$ (ICP OES). ** For ICP OES, not detectable at level of 0.25 $\mathrm{mg} \mathrm{kg}^{-1}(\mathrm{Mn}), 15 \mathrm{mg} \mathrm{kg}^{-1}(\mathrm{Sb}), 12.5 \mathrm{mg} \mathrm{kg}^{-1}(\mathrm{Sn})$ and $5.0 \mathrm{mg} \mathrm{kg}^{-1}(\mathrm{~Pb})$.

\section{CONCLUSION}

The determination of $\mathrm{As}, \mathrm{Fe}, \mathrm{Mn}, \mathrm{Sb}, \mathrm{Sn}$ and $\mathrm{Pb}$ in electrolytic copper could be successfully carried out by ICP OES and ICP-MS. A previous separation of $\mathrm{Cu}$ by electrodeposition is recommended, in order to reduce the metal load introduced into the plasma, being mandatory for the ICP-MS technique, in order to avoid the corrosion of the cones. The ICP-MS provide higher sensitivity and precision, allowing the determination of all analytes in concentrations lower than the limit values, demonstrating to be a powerful technique for the quality control of electrolytic copper manufacturing.

\section{AKNOWLEDGEMENTS}

The authors are thankful to Conselho Nacional de Pesquisas e Desenvolvimento Tecnológico (CNPq, Brazil) and to Financiadora de Estudos e Projetos (FINEP, Brazil) for financial support and/or scholarships.

\section{RESUMO}

O presente trabalho apresenta um estudo comparativo das técnicas ICP-MS e ICP OES com configuração axial e também de dois métodos diferentes de tratamento das amostras, ou seja, por dissolução total com e sem separação do cobre por eletrodeposição, para as determinações de As, Fe, 
$\mathrm{Mn}, \mathrm{Pb}, \mathrm{Sb}$ e $\mathrm{Sn}$ em amostras de cobre eletrolítico. Amostras comerciais e industriais foram dissolvidas com $\mathrm{HNO}_{3} 5 \%$ v/v e o cobre foi eletrodepositado em meio de $\mathrm{HNO}_{3}(1,4 \% \mathrm{v} / \mathrm{v})$ e $\mathrm{H}_{2} \mathrm{SO}_{4}(2,0 \%$ v/v). Verificou-se que a separação do cobre foi eficiente, contudo se constatou contaminação de $\mathrm{Fe}$ e $\mathrm{Sn}$ durante o processo de eletrodeposição. As determinações foram realizadas utilizando-se um ICP OES Axial Varian (Vista Pro) e um ICP-MS Perkin Elmer (Elan Sciex 6000). Foi aplicada a calibração externa, com soluções padrão contendo ou não cobre na concentração equivalente à da amostra. Os limites de detecção $(3 \mathrm{~s}, \mathrm{n}=10)$ para a técnica de ICP OES foram bastante semelhantes na presença ou não do cobre). Já usando ICP-MS, os limites foram melhores na ausência do cobre. Com o objetivo de estabelecer o nível de significância entre as técnicas de quantificação, ou seja, entre ICP OES e ICPMS,foi aplicado o teste $t$ emparelhado, que demonstrou, para um nível de confiança de $95 \%$, não haver diferença significativa, tanto para as soluções sem ou com cobre. Os resultados obtidos no presente trabalho demonstraram que as técnicas ICP-MS e ICP OES fornecem resultados similares em determinadas faixas de concentração dos analitos, podendo ambas serem utilizadas, no controle de qualidade do cobre eletrolítico. Contudo, a técnica ICP-MS foi superior em termos de limite de detecção.

\section{REFERENCES}

ASM (1988), Metals handbook. USA: American Society for Metals. v. 5.

ASTM (1990), Annual Book of ASTM Standards. Methods Test and Analytical Procedures. Section 3. v. 03.05. Standard Test Methods for Chemical Analysis of Copper, E 53 - 86 a. pp. 172-175.

Chiba, K.; Inamoto, I. and Saeki, M. (1990), Application of Isotope Dilution Analysis-Inductively Coupled Plasma Mass Spectrometry to Precise Determination of Silver and Antimony in Pure.

Copper, J. [19--], Anal. Atom. Spectrom., 7, 115-119.

Caruso, J. A. and Wolnik, K. F. (1987), Inductively Coupled Plasma in Analytical Atomic Spectrometry: Injection of Gaseous Samples into Plasmas. Berlim: VHC. pp. 487-525.

ELAN 6000 (1989). User's Guide. ICP-MS training Perkin Elmer Corporation.
Fodes, P. A. (1973), Galvanotécnica Prática. São Paulo: Polígono; USP.

JIS (1988), Japan International Standard: Chemical Analysis of Electrolytic Copper. JIS H 1201.

Jarvis, K. E.; Gray, A. L. and Houk, R. S. (1992), Handbook of Inductively Coupled Plasma Mass Spectrometry. New York: Blackie and Son.

Kumar, S. A.; Sanglikar, M. B.; Shaikh M. S. and Sudersanan, M. (2004), Role of Matrix Material in the Characterization of High - Purity Copper by Flame and Graphite Furnace AAS. Indian J. Chem. Techn., 11 : (2), 170-177.

Lemos, C. H. and Arantes, J. (1982), Perfil Analítico do Cobre. Departamento Nacional de Produção Mineral. (Boletim 56).

Leite, F. V. (2002), Validação em Análise Química. 4 ed. Campinas: Átomo.

Milella, E.; Sentimenti, E. and Mazzetto, G. (1993), Analysis of Impurities in High -Purity Copper by Zeeman Graphite-Furnace AAS. Atom. Spectrosp. 14 : (1), 1-3.

Metals Handbook. Properties and Selection : Nonferrous Alloys and Pure Metals (1979), 2., $9^{\text {th }}$ ed. American Society for Metals.

Nham, T. T. (1999), Fast Analysis of Water Samples.Comparing Axially and Radially Viewed CCD Simultaneous ICP-AES. Varian ICPAES at work, Method ICP-28.

Park, C. J.; Park, S. R.; Yang, S. R.; Han, M. S. and Lee, K. W. (1992), Determination of Trace Impurities in Pure Copper by Isotope Dilution Inductively Coupled Plasma Mass Spectrometry.J. Anal Atom. Spectrom., 7, 641-645.

Thompson, M. (1987), Analytical Performance of Inductively Coupled Plasma Atomic Emission Spectrometry. In: Montaser, A.; Golightly, D.W. Inductively Coupled Plasmas in Analytical Atomic Spectrometry. New York: VHC. pp.175-183.

VARIAN (2000), Vista-Pro. User's Guide. ICP-OES Axial.

Vogel, A. I. (1992), Análise Inorgânica Quantitativa. 5. ed. Rio de Janeiro: Guanabara Koogan.

Received: August 18, 2004; Revised: March 14, 2005 Accepted: August 29, 2005. 